\title{
STRATEGI NAFKAH PEREMPUAN NELAYAN TERHADAP PENDAPATAN KELUARGA
}

\author{
Livelihood Strategy of Coastal Women to Fishermen Family Income
}

Nina Evi Nur Laila*) dan Siti Amanah

Departemen Sains Komunikasi dan Pengembangan Masyarakat, Fakultas Ekologi Manusia IPB

*) Email: nina.evin28@gmail.com

\begin{abstract}
The livelihoods of fishery households are highly vulnerable to fishery sources due to their nature-depending catchments, fishery households in SendangBiru coastal for example. This study focused to analyse the livelihood strategy and contribution of coastal women in SendangBiru to improve their family income. Descriptive and explanatory methods using questionnaire instrument and purposive sampling were used. The responden samples are coastal women who were productively doing activities to obtain extra income for their family. Coastal women of SendangBiru have important roles to improve their family income by spending a lot of time to do productive and reproductive activities. Coastal women's income contributions bring about significant effects on fishery families' financial security. Most of coastal women contributions meet half of their family needs.
\end{abstract}

Keywords: livelihood strategy, coastal women, income contribution, family income

\section{PENDAHULUAN}

Sumberdaya perikanan Indonesia yang melimpah belum diimbangi oleh kualitas sumberdaya manusia pesisir dan sarana penunjang pesisir lainnya. Hal ini membuat masyarakat nelayan masih menjadi masyarakat golongan ekonomi lemah. Pada tahun 2011 tercatat masyarakat miskin di pesisir jumlahnya mencapai 7,87 juta jiwa yang bermukim di 10.000 desa pesisir. Padahal potensi sumberdaya perikanan dan kelautan Indonesia berdasarkan data KKP tahun 2014 adalah 6.520 juta ton/tahun. Hal ini menjadi ironis jika dilihat dari segi kekayaan sumberdaya perikanan dan kelautan Indonesia yang melimpah tetapi masyarakatnya masih dalam ekonomi lemah. Menurut Satria (2009) menyatakan bahwa kemiskinan masyarakat pesisir dapat dibagi menjadi tiga macam, yaitu kemiskinan strukutural, kemiskinan kultural, dan kemiskinan alamiah. Kusnadi dalam Ekaningdyah (2003) menambahkan bahwa kemiskinan yang melekat pada masyarakat pesisir itu disebabkan oleh struktur yang tidak mendukung peningkatan kesejahteraan masyarakat serta budaya yang masih melekat dalam masyarakat tersebut. Tingkat sosial ekonomi dan kesejahteraan hidup yang rendah ini, dalam struktur masyarakat nelayan, menyebabkan nelayan menjadi lapisan sosial yang paling miskin, sedangkan sebagian besar nelayan di Indonesia adalah nelayan buruh. Hal ini menunjukkan bahwa sumberdaya yang melimpah tidak dapat dikelola dan dimanfaatkan dengan maksimal.

Nelayan merupakan suatu golongan di masyarakat yang menggantungkan hidupnya pada perikanan tangkap dan budidaya. Pendapatan yang didapatkan dengan menangkap ikan salah satunya bergantung pada musim. Hal ini berimplikasi pada pendapatan nelayan yang fluktuatif, sedangkan kebutuhan keluarga harus tetap dipenuhi. Agar kebutuhan tetap terpenuhi, maka dalam rumah tangga nelayan melakukan strategi nafkah, salah satunya adalah munculnya peran perempuan. Perempuan nelayan memegang peranan penting dalam mempertahankan ekonomi keluarga. Widodo (2011) menjelaskan bahwa peran perempuan juga menjadi salah satu harapan dalam pengembangan strategi nafkah berkelanjutan. Perempuan dituntut untuk bisa melakukan kegiatan produktif mencari nafkah tambahan di samping harus tetap memelihara rumah tangga dan anak. Perempuan nelayan yang bekerja produktif mencari nafkah tambahan harus mencurahkan waktu lebih banyak daripada laki-laki yang pergi melaut. Hal ini dikarenakan perempuan harus tetap melakukan peran reproduktif dan peran sosialnya untuk mempertahankan masyarakatnya. Banyak faktor yang mendorong perempuan nelayan harus bekerja mencari nafkah tambahan bagi keluarganya, faktor-faktor tersebut meliputi faktor sosial, ekonomi dan budaya. Nelayan bekerja berdasarkan musim, sedangkan perempuan nelayan bekerja sepanjang tahun.

Dusun Sendang Biru, Desa Tambakrejo, Kecamatan Sumbermanjing Wetan, Kabupaten Malang Jawa Timur merupakan wilayah pesisir Indonesia yang dijadikan sebagai pelabuhan ikan internasional. Hasil tangkapan utama pesisir selatan Jawa ini adalah ikan tuna kualitas terbaik yang diekspor ke Jepang dan Australia. Selain sumberdaya perikanan yang melimpah, Dusun Sendang Biru ini juga menjadi salah satu destinasi pariwisata masyarakat Malang dan sekitarnya. Kekayaan dan potensi laut yang cukup besar ini belum mampu memberikan kehidupan yang layak dan sejahtera bagi nelayan setempat, bahkan kemiskinan cenderung tetap menaungi komunitas nelayan di pesisir Pantai Sendangbiru ini. Banyak 
kendala yang menjadi penghambat produktivitas nelayan Sendang Biru, salah satunya keterbatasan teknologi dan infrastruktur. Padahal sebagian besar keluarga di Sendang Biru menyandarkan nasibnya pada penangkapan ikan secara langsung dan tidak langsung.

Kesulitan ekonomi yang dihadapi rumah tangga nelayan membuat perempuan harus membantu mencari nafkah tambahan bagi keluarga nelayan tidak terkecuali di pesisir Sendang Biru. Perempuan pesisir Sendang Biru membantu laki-laki nelayan dalam pemasaran hasil tangkapan serta dalam usaha pengolahan hasil perikanan. Nolan (2011) menjelaskan bahwa ada keterlibatan perempuan Sendang Biru dalam lingkungan kerja mulai dari perdagangan ikan sampai pengaturan usaha perahu milik mereka. Penelitian Nolan menemukan bahwa perempuan Sendang Biru juga memiliki perahu. Selain itu, perempuan Sendang Biru menjadi pedagang kecil, memiliki warung atau toko-toko kecil yang menjual pakaian, alat-alat sekolah atau makanan.

Hal ini menunjukkan bahwa peran perempuan pesisir Sendang Biru sangat strategis dalam upaya peningkatan pendapatan dengan tidak hanya sebatas satu peran saja namun beragam. Berdasarkan latar belakang tersebut, penting untuk dianalisis hubungan strategi nafkah yang dilakukan oleh perempuan nelayan dalam upaya peningkatan kesejahteraan keluarga nelayan di pesisir Sendang Biru.Berdasarkan latar belakang tersebut, kajian ini menganalisis tentang: 1) Mengidentifikasi ragam strategi nafkah perempuan nelayan terhadap pendapatan keluarga, 2)Menganalisis faktor-faktor yang berkaitan dengan strategi nafkah perempuan nelayan, dan 3) Menganalisis kontribusi perempuan nelayan dalam peningkatan pendapatan keluarganya.

\section{METODE PENELITIAN}

Metode yang digunakan adalah metode kualitatif dan kuantitatif. Metode kualitatif dengan cara wawancara mendalam menggunakan panduan pertanyaan penelitian, observasi, dan studi literatur. Metode kuantitatif dilakukan dengan cara wawancara menggunakan kuesioner sebagai instrumen penelitian. Pengambilan data dilaksanakan pada bulan November dan Desember 2015. Penelitian dilakukan di Desa Tambakrejo, Kecamatan Sumbermanjing Wetan, Kabupaten Malang, Jawa Timur. Pemilihan lokasi tersebut dilakukan secara sengaja (purposive) dengan beberapa alasan meliputi:

1. Perairan Sendang Biru sebagai penghasil ikan tuna kualitas ekspor.

2. Perbedaan perekonomian warga yang mencolok ketika musim panen dan musim paceklik.

Responden penelitian ini terdiri dari 30 orang yang dipilih secara purposiveyang memenuhi kriteria sebagai berikut: 1) Perempuan dari rumah tangga nelayan, 2) Aktif melakukan kegiatan produktif menghasilkan pendapatan. Informan dalam penelitian ini meliputi aparat pemerintah desa, pengurus kelembagaan tingkat desa, tokoh masyarakat, dan juragan kapal. Pemilihan informan dilakukan dengan menggunakan teknik purposive.

\section{Gambaran Umum Desa Tambakrejo}

Desa Tambakrejo terletak di wilayah Kecamatan Sumbermanjing Wetan, Kabupaten Malang, Provinsi Jawa Tengah. Desa Tambakrejo terbagi menjadi dua dusun, yaitu: Dusun Tamban dan Dusun Sendang Biru. Desa Tambakrejo berbatasan dengan Desa Sitiarjo di bagian Barat, Tambaksari di sebelah timur, Desa Kedung Banteng di sebelah utara, dan Samudera Hindia di sebelah selatan. Gambar 1 merupakan wilayah Desa Tambakrejo.

Desa Tambakrejo memiliki luas wilayah sebesar 2.700 ha dengan luas pemukiman 146 ha. Desa ini memiliki jumlah penduduk 8.284 jiwa dengan 1.791 jumlah KK yang bertempat tinggal di lahan pemukiman sebesar 146ha. Wilayah desa terdiri dari dua bagian, yaitu wilayah yang berada di Pulau Jawa dan wilayah yang berada di Pulau Sempu. Sebagian besar wilayah desa merupakan hutan lindung dan hutan produksi. Hutan lindung berpusat di Pulau Sempu dengan luas 413,6 ha yang merupakan salah satu destinasi wisata lokal maupun mancanegara dan hutan produksi yang berada di Pulau Jawa dengan luas 2.101,7 ha. Sebagian besar penduduk Desa Tambakrejo beragama Kristen Protestan atau sekitar 58,35\% dari total jumlah penduduknya, sedangkan sisanya beragama Islam atau sekitar 41,65 \% dari jumlah total penduduknya.

Sebagian besar penduduk desa bermatapencaharian sebagai nelayan karena letaknya yang berada di pesisir Samudera Hindia. Luas lahan persawahan hanya mencapai $6,55 \%$ dari luas total wilayah. Hal ini menyebabkan hanya sebagian kecil saja masyarakat yang melakukan kegiatan bercocok tanam yaitu 1110 jiwa. Komoditi utama yang terdapat di desa ini adalah hasil perikanan laut terutama ikan tuna dan tongkol, serta hasil perkebunan berupa kayu jati dan cengkeh. Hasil ikan tuna Sendang Biru merupakan ikan tuna kualitas terbaik sehingga Pelabuhan Ikan Sendang Biru menjadi pelabuhan ikan internasional.

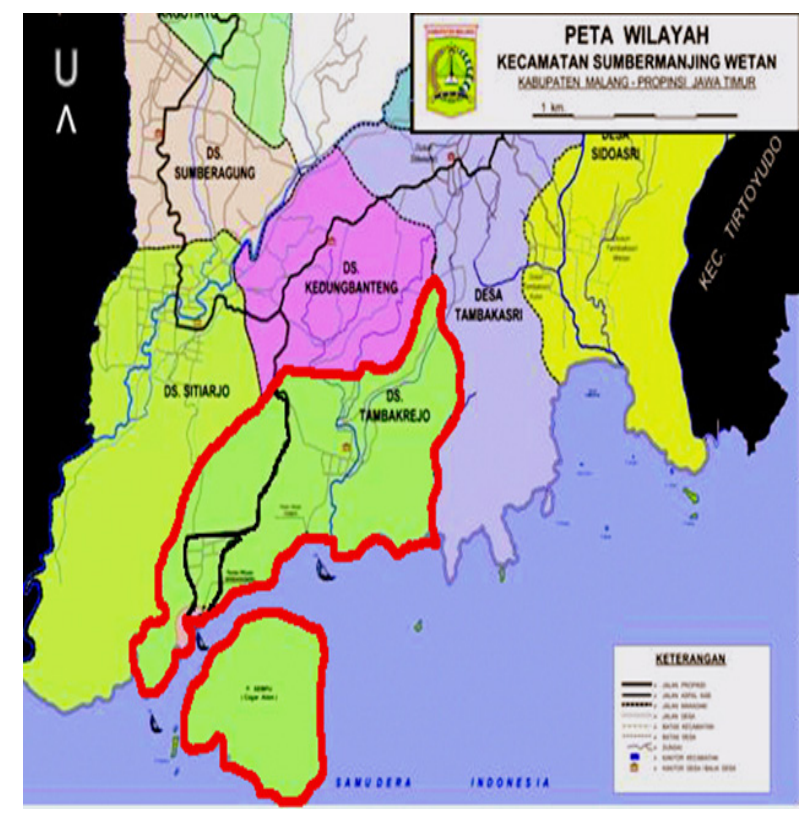

Gambar 1. Peta Desa Tambakrejo (Sumber: Peta Pertanian Kab. Malang) 


\section{Faktor-Faktor Internal dan Eksternal Responden}

\section{Profil Demografi dan Profil Rumah Tangga Responden ${ }^{1}$}

Profil demografi responden meliputi usia responden, asal etnik responden, tingkat pendidikan, jenis/status pekerjaan dan pendapatan yang diperoleh perempuan nelayan dalam kegiatan membantu mencari nafkah bagi keluarganya. Faktor demografi ini berkaitan dengan pemilihan jenis pekerjaan yang diambil oleh responden. Berikut ini merupakan penjelasan untuk setiap komponen profil demografi perempuan nelayan.

\section{1) Usia}

Usia responden dibedakan menjadi tiga kategori, yaitu: Muda (18-30 tahun), Dewasa (31-50 tahun) dan Tua (>50 tahun). Menurut data profil desa, usia produktif penduduk Desa Tambakrejo adalah 18-56 tahun. Pada tahun 2012 tercatat sebanyak 2.110 jiwa penduduk laki-laki dan 1.601 jiwa penduduk perempuan berusia 18-56 tahun yang bekerja secara produktif. Dari data penelitian diperoleh bahwa 26,7\% responden masuk ke dalam kategori Muda, 40\% responden masuk ke dalam kategori Dewasa dan 33,3\% orang responden masuk ke dalam kategori Tua. Dari tiga puluh respoden, terdapat $10 \%$ responden yang berstatus janda. Responden yang berstatus janda dibagi menjadi dua yaitu: cerai dan cerai mati. Terdapat 3,3\% responden yang masuk ke dalam kategori usia muda dengan status janda cerai dan $6,7 \%$ responden kategori usia tua dengan status janda ditinggal meninggal suaminya. Dalam memenuhi kebutuhan rumah tangga, responden tersebut bertindak sebagai kepala keluarga dan tulang punggung utama rumah tangga.

\section{2) Asal Etnik}

Hasil penelitian menunjukkan bahwa terdapat 83,3\% responden dengan Etnik Jawa. Adapun Etnik Jawa yang melekat pada responden ada dua, yaitu: Etnik Jawa Pribumi dan Etnik Jawa Pendatang. Etnik Jawa pribumi merupakan masyarakat jawa asli yang tinggal di Dessa Tambakrejo sedangkan Etnik Jawa Pendatang adalah warga Etnik Jawa yang berasal dari luar Desa Tambakrejo. Responden dengan Etnik Bugis sebanyak 13,3\% dan responden dengan etnik madura 3,3\%. Banyaknya Etnik Jawa Pendatang disebabkan oleh keberadaan dan aktivitas nelayan andon di Desa Tambakrejo. Nelayan-nelayan andon ini ada yang menetap bersama keluarga dari daerah asal mereka dan ada pula yang menikah dengan penduduk asli. Selain itu, adanya nelayan Tambakrejo yang menikah dengan perempuan dari luar desa lalu tinggal dan menetap di Tambakrejo.

\section{3) Tingkat Pendidikan}

Sebagian besar responden merupakan penduduk dengan tingkat pendidikan rendah, yakni $70 \%$ responden. Responden dengan tingkat pendidikan rendah, 57\% 1 Tabulasi silang seluruh faktor internal dan eksternal responden terhadap strategi nafkah tersedia di lampiran responden (12 orang)masuk ke dalam kategori pendidikan rendah yang tidak memiliki ijazah sekolah dasar dan 43\% responden( 9 orang) yang memiliki ijazah sekolah dasar. Responden dengan kategori tingkat pendidikan sedang terdapat $30 \%$ dari seluruh responden, dengan kriteria: $22,2 \%$ (2 orang) tidak tamat sekolah menengah pertama, $66,7 \%$ (6 orang) berijazah sekolah menengah pertama dan $11,1 \%$ (satu orang) yang mempunyai ijazah sekolah menengah atas.

\section{4) Jenis Pekerjaan}

Dari 30 jiwa responden, 60\% responden melakukan kegiatan usaha di sektor offfarm. Kegiatan tersebut meliputi: bakul ikandan membantu di pelelangan. Pilihan pekerjaan sebagai bakul ikan merupakan yang paling banyak dipilih oleh responden yang masuk ke dalam kategori off farm. Responden yang masuk ke dalam kategori pilihan pekerjaan sektor non farmsebanyak 36,7\% responden. Kegiatan non farm tersebut meliputi: penjual sembako, pedagang warung, penjual gorengan, dan TKW. Hanya terdapat 3,3\% responden yang melakukan kegiatan di sektor on farm. Kegiatan tersebut merupakan kegiatan ransum kapal. Kegiatan ini dikategorikan sebagai kegiatan on farm karena ransum kapal merupakan kegiatan yang berhubungan dengan persiapan produksi ikan (penangkapan ikan). Ransum ikan masuk ke dalam pemenuhan logistic $\mathrm{ABK}$.

\section{5) Pendapatan}

Terdapat $16,7 \%$ responden yang mempunyai pendapatan dibawah Rp 500 000/bulan yang termasuk dalam kategori pendapatan rendah. Responden dengan pendapatan Rp500 000,00/bulan adalah responden yang berprofesi sebagai bakul ikan kecil dan pedagang warung. Responden dengan pendapatan antara Rp 500 000/bulan - Rp 1500 000/ bulan terdapat $6,7 \%$ yang berprofesi sebagai pedagang warung pinggir pantai dan tenaga pembantu di pelelangan. Sebagian besar responden (76,7\%) mempunyai pendapatan di atas Rp 1500 000/bulan. responden dengan pendapatan tinggi tersebut, 74\% responden berprofesi sebagai bakul ikan di TPI dengan penghasilan rata-rata Rp 3000 000/ bulan, sisanya berprofesi sebagai pedagang warung dan profesi lainnya.

\section{6) Etnik Dominan Keluarga}

Sebesar 83,3\% latar belakang etnik keluarga responden adalah Etnik Jawa. Terdapat 25 responden dengan latar belakang Etnik Jawa. Jumlah tersebut sama dengan jumlah sebaran responden berdasarkan Etnik Asal responden. Namun terdapat enam responden yang berbeda antara Etnik Asal dengan Etnik Keluarganya. Hal ini terjadi karena adanya perkawinan beda etnik. Responden Etnik Jawa yang mempunyai latar belakang keluarga Etnik Jawa terdapat 22 responden. Kemudian responden dengan Etnik Jawa yang mempunyai latar belakang etnik keluarga berbeda terdapat tiga responden. Dari ketiga responden tersebut diketahui bahwa satu responden Etnik Jawa mempunyai latar belakang etnik keluarga dari Etnik Bajo dan dua responden Etnik Jawa dengan latar belakang etnik 
Tabel 1. Jumlah dan Persentase Rumah Tangga Berdasarkan Etnik Asal dan Latar Belakang Etnik Keluarga

\begin{tabular}{lrcccr}
\hline \multirow{2}{*}{$\begin{array}{c}\text { Etnik } \\
\text { Asal }\end{array}$} & \multicolumn{5}{c}{ LatarBelakangEtnikKelu- } \\
\cline { 2 - 5 } & Jawa & Bugis & $\begin{array}{c}\text { Madu- } \\
\text { ra }\end{array}$ & Bajo & \\
\hline Jawa & 22 & 0 & 2 & 1 & 25 \\
Bugis & 3 & 1 & 0 & 0 & 4 \\
Madura & 0 & 0 & 1 & 0 & 1 \\
\hline Jumlah & 25 & 1 & 3 & 1 & \\
\hline
\end{tabular}

keluarga dari Madura. Selain itu terdapat tiga responden bukan Etnik Jawa yang mempunyai latar belakang etnik keluarga Etnik Jawa. Ketiga responden merupakan responden dengan Etnik Bugis.

Tabel 1 menyajikan data latar belakang etnik keluarga responden dari Etnik Jawa, Bugis, Madura dan Lainnya, dari hasil penelitian merujuk pada Etnik Bajo. Terdapat satu responden dengan latar belakang etnik keluarga Etnik Bugis, satu responden dengan latar belakang etnik keluarga Etnik Bajo dan tiga responden dengan dengan latar belakang etnik keluarga Etnik Madura. Responden dengan latar belakang etnik keluarga Etnik Bugis merupakan responden dengan Etnik Bugis. Sedangkan responden dengan latar belakang etnik keluarga Etnik Bajo merupakan responden dengan Etnik Jawa. Tiga responden yang berlatar belakang etnik keluarga dari Etnik Madura tebagi menjadi dua, yaitu dua responden dengan Etnik Jawa dan satu responden dengan Etnik Madura.

\section{7) Jumlah Anggota Rumah Tangga}

Dari data penelitian diketahui bahwa sebanyak 46,7\% responden yang tinggal di dalam rumah tangga dengan jumlah anggota rumah tangga tergolong kecil yakni 1-3 orang. Responden dengan jumlah anggota rumah tangga kecil mempunyai dua kemungkinan. Pertama, rumah tangga dengan jumlah anggota rumah tangga 2 orang. Kedua, responden dengan jumlah anggota rumah tangga kecil adalah rumah tangga dengan jumlah anggota rumah tangga 3 orang. Responden dengan jumlah anggota rumah tangga 3 orang terdapat 8 responden. Rumah tangga dengan jumlah anggota rumah tangga 3 orang ini semuanya merupakan keluarga inti yang terdiri dari ayah, ibu dan satu orang anak. Rumah tangga responden dengan jumlah anggota rumah tangga sedang terdapat 43,3\% responden. Rumah tangga responden kategori jumlah anggota rumah tangga sedang ini terdiri dari ayah, ibu dan 2 atau 3 anak. Adapun responden yang mempunyai jumlah anggota rumah tangga tinggi sebanyak 10\% dengan anggota keluarga ibu, anak dan cucu. Responden yang demikian merupakan responden yang telah mengalami usia lanjut.

\section{8) Mata Pencaharian Utama Keluarga}

Seluruh responden menyampaikan bahwa mata pencaharian utama rumah tangga adalah sebagai nelayan (tangkap dan $\mathrm{ABK})$.

\section{9) Pendapatan Rumah Tangga}

Sebesar 50\% responden merupakan rumah tangga kategori tinggi dengan pendapatan rata-rata di atas Rp5 700 000,00/ bulan. Bahkan salah satu responden menyatakan bahwa setiap bulan pendapatan suami ketika musim panen tuna bisa mencapai angka Rp500 000 000/bulan. Kepala keluarga dari responden tersebut merupakan nelayan yang mempunyai kapal besar (bisa dikatakan responden tersebut berasal dari juragan kapal). Terdapat 20\% rumah tangga responden termasuk ke dalam kategori tingkat pendapatan rumah tangga rendah yaitu $\leq$ Rp3 600 000/bulan. Pendapatan rumah tangga terkecil dari seluruh total responden adalah Rp1 300 000/bulan. Mata pencaharian utama rumah tangga responden tersebut adalah nelayan jungkung fiber yang mencari ikan karang.

\section{Faktor Eksternal}

Faktor eksternal perempuan nelayan merupakan faktorfaktor luar yang berhubungan dengan kehidupan rumah tangga nelayan. Faktor-faktor tersebut antara lain: akses terhadap sumberdaya modal, ikatan patron-client dan

Tabel 2. Jumlah dan Presentase Faktor Eksternal Respoden

\begin{tabular}{llrrr}
\hline \multicolumn{1}{c}{ Komponen } & Kategori & Jumlah (jiwa) & Persentase (\%) & \% Kumulatif \\
\hline \multirow{3}{*}{ Akses Sumberdaya Modal } & Sulit & 8 & 26,7 & 26,7 \\
& Sedang & 21 & 70 & 96,7 \\
& Mudah & 1 & 3,3 & 100 \\
\multirow{3}{*}{ Ikatan Patron-Client } & Lemah & 1 & 3,3 & 3,3 \\
& Sedang & 25 & 83,3 & 86,7 \\
\multirow{2}{*}{ Dukungan Sosial } & Kuat & 4 & 13,3 & 100 \\
& Lemah & 0 & 0 & 0 \\
& Sedang & 18 & 60,0 & 60,0 \\
& Kuat & 12 & 40,0 & 100,0 \\
\hline
\end{tabular}


Tabel 3. Jumlah dan PersentaseAlokasi Waktu Perempuan Pesisir dalam Kegiatan Reproduktif, Produktif dan Sosial

\begin{tabular}{|c|c|c|c|c|c|c|}
\hline \multirow{3}{*}{ Kategori } & \multicolumn{6}{|c|}{ Alokasi Waktu } \\
\hline & \multicolumn{2}{|c|}{ Reproduktif (Domestik) } & \multicolumn{2}{|c|}{ Produktif } & \multicolumn{2}{|c|}{ Sosial } \\
\hline & Jumlah (jiwa) & $\%$ & Jumlah (jiwa) & $\%$ & Jumlah (jiwa) & $\%$ \\
\hline Rendah & 3 & 10,0 & 4 & 13,3 & 9 & 30,0 \\
\hline Sedang & 23 & 76,6 & 24 & 80,0 & 17 & 56,7 \\
\hline Tinggi & 4 & 13,3 & 2 & 6,7 & 4 & 13,3 \\
\hline Jumlah & 30 & 100 & 30 & 100 & 30 & 100 \\
\hline
\end{tabular}

dukungan sosial yang diperoleh perempuan nelayan dalam kehiduan sosialnya. Pengukuran akses sumberdaya modal responden ditentukan oleh jenis modal yang diterima responden, efektivias modal dan kemudahan akses modal. Pengukuran tingkat keterikatan patron-client responden ditentukan melalui baik dan tidak baiknya hubungan yang terjalin, lama hubungan yang terjalin, jumlah modal yang bisa diakses, dan adanya tidaknya pengaruh patron di dalam menentukan keputusan komunitas. Kemudian, pengukuran dukungan sosial yang diterima responden dilakukan dengan mengukur tiga aspek, yaitu: keberadaan hubungan kekerabatan/pertemanan/keorganisasian, adanya sharing memberikan solusi dan pengaruh dukungan sosial di dalam komunitas. Tabel 1 dibawah ini menunjukkan jumlah dan persentase faktor eksternal responden.

\section{Strategi Nafkah Perempuan Nelayan}

\section{Curahan Waktu}

Sebagian besar responden meleuangkan waktu yang cukup besar untuk kegiatan reproduktif mengurus rumah tangga dan kegiatan produktif mencari tambahan pendapatan keluarga. Rata-rata responden mengalokasikan waktu lebih dari 10 jam dalam sehari untuk melakukan masing-masing kegiatan reproduktif(domestik) dan produktif. Waktu yang diluangkan untuk kegiatan reproduktif (domestik) dan produktif dihitung dalam jam setiap hari. Sedangkan waktu yang diluangkan untuk kegiatan sosial dihitung dalam jam setiap minggu. Jenis data yang digunakan adalah jenis data ordinal dengan tiga ketgori yaitu rendah, sedang dan tinggi. Perhitungan rentang kategori dilakukan berdasarkan data emik di lapangan. Rentang waktu untuk kegiatan produktif dan reproduktif setiap kategori alokasi waktu sebagai berikut: 1) Rendah, jika alokasi waktu $<11$ jam/hari, 2) sedang, jika alokasi waktu 11-13jam/hari dan 3) tinggi, jika alokasi waktu $>13$ jam/hari. Tabel berikut ini menyajikan sebaran responden berdasarkan alokasi waktu kegiatan

Tabel 4. Jumlah dan Persentase Migrasi Responden

\begin{tabular}{lccc}
\hline Kategori & $\begin{array}{c}\text { Jumlah } \\
\text { (jiwa) }\end{array}$ & $\begin{array}{c}\text { Persentase } \\
(\%)\end{array}$ & \% Kumulatif \\
\hline Tidak & 21 & 70 & 70 \\
Ya & 9 & 30 & 100 \\
\hline Total & 30 & 100 & \\
\hline
\end{tabular}

reproduktif (domestik), produktif dan sosial.

Seluruh responden hampir tidak mempunyai waktu untuk melakukan kegiatan sosial. Satu-satunya kegiatan sosial yang diikuti oleh responden adalah kebaktian keluarga yang khusus dilakukan oleh responden yang beragama Kristen Protestan. Kegiatan kebaktian keluarga tersebut selain bersifat religi, namun juga bermakna sebagai momen berkumpul bersama kerabat dan tetangga sekitar. Kebaktian keluarga dilakukan secara bergiliran di rumah warga. Adapun yang hadir dalam kebaktian keluarga yang diselenggarakan secara berkelompok tersebut adalah yang masih berhubungan saudara atau yang mempunyai hubungan dekat dengan tuan rumah. Seluruh responden tidak mengikuti organisasi sosial tingkat desa, namun ketika ada ajakan untuk mengikuti kegiatan sejenis penyuluhan dan pelatihan keterampilan, responden mau meluangkan waktu untuk mengikuti kegiatan tersebut sepanjang tidak menyita banyak waktu dari responden.

\section{Pola Nafkah}

Pola nafkah mencakup pola nafkah tunggal dan pola nafkah ganda. Responden dengan pola nafkah tunggal berarti bahwa responden tersebut menekuni satu subsektor kegiatan produktif sebagai upaya mencari penghasilan. Sedangkan pola nafkah ganda berarti responden melakukan usaha pada lebih dari satu subsektor usaha untuk mendapatkan penghasilan. Subsektor usaha yang dimaksud dibagi menjadi tiga, yakni: subsektor on farm, off farm dan non farm.Sebanyak 26 orang responden melakukan pola nafkah tunggal dan 4 orang responden dengan pola nafkah ganda. Responden yang melakukan pola nafkah tunggal terdapat 17 orang berprofesi sebagai bakul ikan dan 9

Tabel 5. Jumlah dan Persentase Kontribusi Pendapatan Perempuan Nelayan terhadap Pendapatan Keluarga

\begin{tabular}{lccc}
\hline \multicolumn{1}{c}{ Kategori } & $\begin{array}{c}\text { Jumlah } \\
\text { (jiwa) }\end{array}$ & $\begin{array}{c}\text { Persentase } \\
(\%)\end{array}$ & $\begin{array}{c}\text { \% Kumu- } \\
\text { latif }\end{array}$ \\
\hline $\begin{array}{l}\text { Rendah } \\
(10 \%-25 \%)\end{array}$ & 7 & 23,3 & 23,3 \\
$\begin{array}{l}\text { Sedang } \\
(25 \%<x<50 \%)\end{array}$ & 11 & 36,7 & 60 \\
$\begin{array}{l}\text { Tinggi } \\
(\geq 50 \%)\end{array}$ & 12 & 40 & 100 \\
\hline Total & 30 & 100 & \\
\hline
\end{tabular}


orang lainnya di sektor off farm. Kombinasi pola nafkah dari 4 orang responden dengan pola nafkah ganda adalah sebagai berikut: 3 orang dengan kombinasi off farm-non farm dan satu orang dengan kombinasi on farm-non farm.

\section{Migrasi}

Penentuan kategori dalam kegiatan migrasi dilakukan dengan mempertimbangkan dua hal, yaitu: jarak tempat tinggal tetap menuju sumber nafkah dan waktu tempuh yang diluangkan untuk menuju sumber nafkah. Jarak dibagi menjadi dua kategori, yaitu berada dalam satu desa dan berada di luar desa tempat tinggal. Sedangkan waktu tempuh dibagi menjadi dua kategori, yaitu: sebentar dan lama. Jarak dan waktu tempuh mengacu pada jarak desa terdekat dengan Desa Tambakrejo dan waktu tempuh tercepatnya. Jarak desa terdekat dari Tambakrejo adalah $7 \mathrm{~km}$ dengan waktu tempuh 30 menit dengan menggunakan kendaraan bermotor. Tabel 3 berikut ini menyajikan jumlah dan persentase migrasi responden.

Responden yang tidak melakukan migrasi merupakan penduduk pribumi dan pendatang yang memutuskan menjadi warga desa. Dalam penelitian ini terdapat satu responden pendatang yang memutuskan untuk tinggal dan menetap di Tambakrejo. Responden tersebut berasal dari Pulau Madura dan menetap di Tambakrejo beserta keluarganya. Responden tersebut tidak melakukan perjalanan "mudik" yang umum dilakukan oleh warga pendatang lain ketika musim paceklik tiba.

\section{Optimalisasi Sumberdaya Keluarga}

Rumah tangga dengan jumlah anggota rumah tangga banyak cenderung memanfaatkan sumberdaya keluarga sebagai salah satu sumber nafkah tambahan dan tenaga pemeliharaan rumah tangga. Optimalisasi sumberdaya dilihat dari anggota rumah tangga selain kepala keluarga dan perempuan nelayan yang turut berkontribusi dalam pemenuhan kebutuhan rumah tangga dan yang turut membantu melakukan pekerjaan domestik. Berdasarkan hasil penelitian, terdapat 10 rumah tangga responden yang melakukan optimalisasi sumberdaya keluarga. Sebanyak 20 responden tidak melakukan optimalisasi sumberdaya keluarga. Responden yang tidak melakukan optimalisasi sumberdaya keluarga adalah responden dengan jumlah anggota rumah tangga di bawah empat orang. Responden yang tidak melakukan optimalisasi sumberdaya keluarga memanfaatkan pendapatan kepala keluarga dan pendapatan tamabhan yang ia peroleh untuk memenuhi kebutuhan rumah tangga. Kepala rumah tangga responden membantu kegiatan domestik seperti menyapu dan mengepel sedangkan kegiatan domestik lain dikerjakan oleh perempuan (istri). Sebanyak 10 responden melakukan optimalisasi sumberdaya keluarga. Responden yang melakukan optimalisasi sumberdaya keluarga memanfaatkan tenaga anak dan menantu untuk membantu mencari nafkah tambahan dan berbagi peran dalam melakukan pekerjaan domestik. Optimalisasi sumberdaya keluarga bergantung pada jumlah anggota rumah tangga yang berimplikasi pada pemenuhan serta pemeliharaan rumah tangga. Semakin banyak beban kebutuhan rumah tangga, maka semakin berat pula tanggungjawab perempuan (istri) untuk melakukan strategi guna menjaga keberlangsungan perekonomian rumahtangga.

\section{Kontribusi Pendapatan Perempuan terhadap Pendapatan Rumah Tangga}

Perempuan nelayan menyumbangkan pendapatannya untuk membantu memenuhi kebutuhan rumah tangga. Perempuan nelayan mengalokasikan seluruh pendapatannya untuk mempertahankan perekonomian keluarga. Kategori kontribusi perempuan nelayan dibagi menjadi tiga, yaitu kontribusi rendah, sedang dan tinggi. Dikatakan kontribusi rendah jika pendapatan perempuan nelayan yang disumbangkan untuk memenuhi kebutuhan rumah tangga nelayan lebih kecil sama dengan $25 \%$. Hal ini berarti bahwa nol sampai seperempat kebutuhan rumah tangga ditanggung oleh perempuan. Perempuan nelayan yang termasuk ke dalam kontribusi sedang adalah yang memberi sumbangan pendapatan sebesar $25 \%<x<50 \%$ untuk membantu memenuhi kebutuhan rumah tangga nelayan. Responden dengan kontribusi sedang memenuhi lebih dari seperempat hingga setengah dari kebutuhan rumah tangga nelayan. Jika sampai setengah kebutuhan rumah tangga dipenuhi oleh perempuan, maka posisi perempuan di dalam mempertahankan ekonomi rumah tangga dianggap penting. Kemudian, perempuan yang menyumbangkan pendapatannya untuk memenuhi lebih dari setengah kebutuhan rumah tangga masuk ke dalam kategori kontribusi tinggi. Perempuan dengan tingkat kontribusi tinggi memiliki posisi yang sangat penting di dalam memenuhi kebutuhan rumah tangga. Tabel 4 berikut ini menyajikan jumlah dan persentase kontribusi pendapatan responden (perempuan nelayan) terhadap pendapatan keluarga.

Dari Tabel 4 diketahui bahwa posisi perempuan nelayan sangat penting dalam mempertahankan perekonomian rumahtangga. Sebanyak 12 orang responden mempunyai kontribusi pendapatan sebesar 50\% dari pendapatan rumah tangga. Hal ini berimplikasi bahwa setengah dari total kebutuhan rumah tangga ditanggung oleh perempuan. Selain melakukan kegiatan aktif mencari nafkah tambahan, perempuan nelayan juga turut berperan dalam strategi saving.

Saving strategy yang umum dilakukan oleh penduduk di Sedang Biru adalah menyimpan uang dalam bentuk perhiasan emas. Seluruh responden membeli perhiasan emas dengan maksud agar mudah untuk diuangkan ketika membutuhkan terlebih nilai emas yang dianggap hampir stabil. Hal ini untuk mengurangi kerugian atau selisih antara pembelian dan penjualan. Selain menabung dalam bentuk emas, keluarga nelayan membeli kendaraan bermotor dan barang elektronik lainnya. Kendaraan bermotor dan barang elektronik mempunyai nilai investasi menyusut karena harga jual lebih murah daripada harga beli. Penyusutan tersebut terjadi karena penggunaan kendaraan dan barang elektronik tersebut. Namun demikian, pembelian kendaraan bermotor dan barang elektronik masih menjadi salah satu alternatif menyimpan uang.

Masyarakat yang bergabung di kelembagaan pedagang asongan Pantai Sendang Biru menyelenggarakan tabungan harian bagi anggota. Setiap hari setiap anggota wajib 
Tabel 6. Persentase Faktor Internal dan Eksternal Responden terhadap Strategi Nafkah

\begin{tabular}{|c|c|c|c|c|c|c|c|}
\hline \multirow{3}{*}{ Variabel } & \multirow{3}{*}{ Kategori } & \multicolumn{4}{|c|}{ Optimalisasi Sumberdaya Keluarga } & \multirow{2}{*}{\multicolumn{2}{|c|}{ Total }} \\
\hline & & \multicolumn{2}{|c|}{ Tidak } & \multicolumn{2}{|c|}{ Ya } & & \\
\hline & & $\mathbf{N}$ & $\%$ & $\mathbf{N}$ & $\%$ & $\mathbf{N}$ & $\%$ \\
\hline \multirow{3}{*}{ Usia } & Muda & 8 & 100 & 0 & 0 & 8 & 100 \\
\hline & Dewasa & 8 & 67 & 4 & 33 & 12 & 100 \\
\hline & Tua & 4 & 40 & 6 & 60 & 10 & 100 \\
\hline \multirow{5}{*}{$\begin{array}{l}\text { Tingkat } \\
\begin{array}{l}\text { Pendi- } \\
\text { dikan }\end{array}\end{array}$} & Jumlah & 20 & & 10 & & 30 & \\
\hline & Rendah & 11 & 52 & 10 & 48 & 21 & 100 \\
\hline & Sedang & 9 & 100 & 0 & 0 & 9 & 100 \\
\hline & Tinggi & 0 & 0 & $c$ & 0 & 0 & 0 \\
\hline & Jumlah & 20 & & 10 & & 30 & \\
\hline \multirow{3}{*}{ Variabel } & \multirow{3}{*}{ Kategori } & \multicolumn{4}{|c|}{ Migrasi } & \multirow{2}{*}{\multicolumn{2}{|c|}{ Total }} \\
\hline & & Tidak & & Ya & & & \\
\hline & & $\mathbf{N}$ & $\%$ & $\mathbf{N}$ & $\%$ & $\mathbf{N}$ & $\%$ \\
\hline \multirow{3}{*}{$\begin{array}{l}\text { DukunganSo- } \\
\text { sial }\end{array}$} & Lemah & 0 & 0 & 0 & 0 & 0 & 0 \\
\hline & Sedang & 10 & 55 & $\varepsilon$ & 45 & 18 & 100 \\
\hline & Kuat & 11 & 92 & & 8 & 12 & 100 \\
\hline \multirow{5}{*}{ Asal Etnik } & Jumlah & 21 & & 9 & & 30 & \\
\hline & Jawa & 20 & 80 & 5 & 20 & 25 & 100 \\
\hline & Bugis & 0 & 0 & 4 & 100 & 4 & 100 \\
\hline & Madura & 1 & 100 & $c$ & 0 & 1 & \\
\hline & Jumlah & 21 & & 9 & & 30 & \\
\hline \multirow{3}{*}{ Variabel } & \multirow{3}{*}{ Kategori } & \multicolumn{4}{|c|}{ Pola Nafkah } & \multirow{2}{*}{\multicolumn{2}{|c|}{ Total }} \\
\hline & & Tung & & & & & \\
\hline & & $\mathbf{N}$ & $\%$ & $\mathbf{N}$ & $\%$ & $\mathbf{N}$ & $\%$ \\
\hline \multirow{3}{*}{ Asal Etnik } & Jawa & 22 & 88 & 3 & 12 & 25 & 100 \\
\hline & Bugis & 4 & 100 & 0 & 0 & 4 & 100 \\
\hline & Madura & 0 & 0 & & 100 & 1 & 100 \\
\hline \multirow{5}{*}{$\begin{array}{c}\text { Jenis peker- } \\
\text { jaan }\end{array}$} & Jumlah & 26 & & 4 & & 30 & \\
\hline & On farm & 0 & 0 & & 100 & 1 & 100 \\
\hline & Off farm & 17 & 94 & & 6 & 18 & 100 \\
\hline & Non farm & 9 & 82 & 2 & 18 & 11 & 100 \\
\hline & Jumlah & 26 & & 4 & & 30 & \\
\hline
\end{tabular}

membayarkan Rp10.000,00 kepada petugas tagihan. Tabungan tersebut digunakan untuk kegiatan rekreasi bersama atau untuk dibagikan kembali setelah satu tahun pengumpulan. Komunitas bakul ikan di TPI pun memiliki kelembagaan tabungan harian yang sama, namun jumlah yang harus disetorkan setiap harinya adalah Rp50.000,00 dan Rp100.000,00. Hasil dari tabungan tersebut dibagikan ketika Hari Lebaran. Kelembagaan ini sangat bermanfaat bagi bakul ikan, sebab proses pencairan tabungan berjangka sehingga bakul ikan tidak dapat mengambil uang tabungannya sewaktu-waktu. Jenis tabungan yang sifatnya wajib dibayar tiap hari ini mirip dengan sistem pada tabungan rencana pada bank-bank konvensional. Nasabah melakukan kesepakatan jangka waktu untuk bisa mencairkan tabungan mereka.Di Sendang Biru sudah terdapat satu bank BUMN. Keberadaan bank tersebut sangat membantu sebagian besar masyarakat dalam segi simpan dan pinjam uang. Selain itu, juragan kapal juga menerapkan sistem penangguhan pembayaran gaji ABK. Penangguhan pembayaran ini bermaksud untuk menahan ABK tersebut agar tetap menjadi awak kapal dari juragan tersebut. Tidak semua upah ABK dapat dicairkan secara langsung. Upah yang ditahan oleh juragan akan diberikan secara berkala. Selain untuk mengikat ABK, sistem ini juga dapat membantu keluarga nelayan dalam upaya menyimpan uang.

\section{Hubungan antara Faktor Internal dan Eksternal Perempuan Nelayan dengan Strategi Nafkah}

Faktor yang berhubungan dengan strategi nafkah ${ }^{2}$ adalah 2 Dilihat dari nilai signifikasi uji Rank Spearman 
pertama, faktor usia sangat berhubungan positif dengan optimalisasi sumberdaya keluarga dengan nilai signifikasi 0,06 . Responden dengan umur tua lebih cenderung melakukan strategi mengoptimalisasikan sumberdaya keluarga daripada responden dengan umur muda dan dewasa. Hal ini bisa terjadi karena umumnya responden kategori tua mempunyai anggota rumah tangga lebih besar daripada responden umur muda ataupun dewasa. Seluruh responden berusia muda sama sekali tidak melakukan optimalisasi sumberdaya keluarga dan responden berusia tua cenderung melakukan optimalisasi sumberdaya keluarga. Responden berusia dewasa sebagian besar, yakni sebanyak $67 \%$, tidak melakukan optimalisasi sumberdaya keluarga dan 33\% lainnya telah melakukan optimalisasi sumberdaya keluarga. hal ini berimplikasi pada semakin semakin muda usia responden maka kesempatan melakukan optimalisasi sumberdaya keluarga semakin kecil dan semakin tua usia responden maka kesempatan melakukan optimalisasi sumberdaya keluarga semakin besar pula. Responden umur dewasa yang mempunyai anggota rumah tangga banyak juga melakukan strategi optimalisasi sumberdaya keluarga daripada keluarga yang mempunyai anggota rumah tangga kecil. Nugraheni (2012) menyatakan bahwa anggota keluarga yang semakin besar maka peran wanita (istri nelayan) akan semakin besar untuk menutupi kebutuhan ekonomi yang semakin besar dengan bertambahnya jumlah anggota keluarga. Hal ini berimplikasi dengan jumlah anggota keluarga pada responden usia dewasa dan tua yang besar membuat responden harus melakukan strategi nafkah optimalisasi sumberdaya keluarga dengan memanfaatkan tenaga anggota keluarga (khususnya anak) untuk membantu mencari nafkah tambahan untuk memenuhi kebutuhan rumah tangga.

Kedua, faktor tingkat pendidikan responden berhubungan negatif terhadap optimalisasi sumberdaya keluarga dengan nilai signifikasi 0,10 . Hal ini menunjukkan bahwa semakin tinggi tingkat pendidikan responden maka semakin kecil kemungkinannya untuk melakukan optimalisasi sumberdaya keluarga. Dari hasil data lapangan, tidak terdapat responden dengan kategori tingkat pendidikan di atas Sekolah Menengah Atas. Sebanyak 52\% responden dengan kategori tingkat pendidikan rendah melakukan optimalisasi sumberdaya keluarga dan 48\% lainnya tidak. Hal berbeda terlihat pada responden dengan tingkat pendidikan sedang yang seluruhnya tidak melakukan optimalisasi sumberdaya keluarga.Hal ini dapat menunjukkan bahwa responden dengan tingkat pendidikan sedang tidak melakukan optimalisasi sumberdaya keluarga. Semakin tinggi tingkat pendidikan responden, maka semakin kecil untuk melakukan optimalisasi sumberdaya keluarga. Zid (2011) menyatakan bahwa anak-anak pada keluarga miskin memasuki dunia kerja lebih awal jika dibandingkan dengan anak-anak pada keluarga berkecukupan. Banyaknya jumlah anak pada keluarga nelayan berbanding terbalik dengan tingkat pendidikan mereka. Dengan demikian, perempuan nelayan dengan tingkat pendidikan yang tinggi akan memberikan pendidikan yang layak untuk anak-anaknya dan tidak memanfaatkan tenaga anak untuk berkontribusi kepada keluarga. Tabel 5 menyajikan persentase faktor internal dan eksternal responden terhadap strategi nafkah.
Ketiga, terdapat hubungan negatif antara dukungan sosial dengan migrasi dengan nilai signifikasi 0,035 dengan correlation coefficients -0,386. Sebanyak 55\% responden dengan dukungan sosial sedang tidak melakukan migrasi dan 45\% lainnya memilih melakukan kegiatan migrasi. Hal ini berbanding lurus dengan sebanyak $92 \%$ responden dengan tingkat dukungan sosial tinggi tidak melakukan migrasi dan 8\% lainnya melakukan migrasi. Hal tersebut memperkuat bahwa semakin tinggi tingkat dukungan sosial yang diperoleh seseorang maka semakin kecil pula keinginan untuk melakukan migrasi.Dukungan sosial yang umumnya diberikan oleh kerabat dekat adalah sebagai rekan pemberi semangat, tempat curhat $^{3}$, tempat meminjam uang, dan sumber informasi. Jika tingkat dukungan sosial yang diperoleh perempuan tinggi, maka perempuan akan merasa nyaman berada di lingkungannya dan akses terhadap sumber informasi akan besar pula. Hal ini mempermudah perempuan dalam mencari pekerjaan di sekitar lingkungan. Jika tingkat dukungan sosial yang diterima oleh perempuan rendah, maka perempuan akan cenderung mencari sumber pendapatan keluar daerahnya karena keterbatasan informasi yang dia terima dari orang-orang disekitarnya.

Keempat, asal etnik responden berhubungan dengan pola nafkah responden. Dari data yang telah dihimpun di lapangan, responden dengan Etnik Jawa lebih cenderung melakukan pola nafkah tunggal. Responden dengan Etnis Jawa berjumlah 25 jiwa, 22\% di antaranya melakukan pola nafkah ganda dan $88 \%$ melakukan pola nafkah tunggal. Responden dengan Etnis Bugis juga melakukan pola nafkah tunggal (dalam penelitian ini 4 jiwa responden dengan Etnis Bugis seluruhnya bekerja sebagai bakul ikan). Sedangkan Etnis Madura yang berjumlah satu jiwa melakukan kegiatan pola nafkah ganda. Etnis Madura memang dikenal sebagai salah satu etnis yang mempunyai semangat bekerja yang tinggi dan gemar merantau ke daerah lain untuk memperoleh pekerjaan yang layak.

Kelima, terdapat hubungan antara asal etnik responden dengan migrasi. Responden dengan Etnik Jawa (seperti yang telah dijelaskan pada Sub Bab sebelumnya) terbagi menjadi dua, yaitu Jawa Pribumi dan Jawa Pendatang. Responden dengan Etnik Jawa yang melakukan migrasi terdapat 20\% dari responden Etnik Jawa. Responden dengan Etnik Jawa sebagian besar tidak bermigrasi karena responden tersebut tinggal dan menetap serta melakukan kegiatan produktifnya di Desa Tambakrejo. Sedangkan Responden dengan Etnik Bugis seluruhnya melakukan kegiatan produktifnya dengan bermigrasi. Responden dengan Etnik Bugis melakukan kegiatan produktifnya sebagai bakul ikan ketika musim panen dan akan kembali ke daerah asalnya ketika musim paceklik. Responden dengan Etnik Madura tidak melakukan migrasi karena sudah menjadi penduduk Desa Tambakrejo.

Etnis Bugis dan Madura merupakan salah satu etnis asli Indonesia yang terkenal dengan kegemarannya melakukan

3 Curhat merupakan kepanjangan dari curahan hati yang bermakna sebagai tempat mencurahkan keluh kesah yang diaami dan meminta saran/solusi terhadap masalah yang dihadapi. Hal ini sangat umum sekali dilakukan oleh perempuan. 
migrasi. Etnis tersebut menyebar hampir di semua wilayah pesisir Indonesia. Fenomena nelayan andon juga mendukung adanya migrasi ini. Nelayan yang melakukan andon memboyong istri bahkan keluarganya untuk ikut bermigrasi. Responden yang melakukan migrasi dalam upayanya mencari nafkah tambahan juga bergantung suami mereka kecuali responden yang menjadi TKW di Malaysia. Dengan demikian dapat ditarik kesimpulan bahwa yang mempunyai kecenderungan kecil untuk melakukan migrasi adalah responden dengan Etnik Jawa, sedangkan Etnik Bugis mempunyai kecenderungan besar dalam melakukan migrasi. Nordholt dan Klinken (2007) menyatakakan bahwa Bugis terkenal pada kecenderungan mereka 'merantau': mengadu nasib dengan bermigrasi agar bisa pulang membawa uang sehingga bisa beli tanah dan meningkatkan status keluarga.

Keenam, terdapat hubungan antara jenis pekerjaan dengan pola nafkah. terdapat $13,3 \%$ responden yang melakukan pola nafkah ganda. Responden dengan jenis pekerjaan on farm melakukan strategi nafkah ganda. Responden tersebut melakukan pola nafkah ganda karena pekerjaan utamanya sebagai tukang ransum kapal hanya dilakukan ketika kapal akan melaut, seusai itu responden membuka warung kecil yang menjual jajanan anak-anak di pelataran rumahnya. Hal tersebut dilakukan responden untuk mengisi waktu luangnya. Responden lain yang melakukan pola nafkah ganda adalah 3,3\% responden pada sektor off farm dan $6,7 \%$ responden pada sektor non farm. Responden yang melakukan pola nafkah ganda adalah responden yang melakukan kegiatan "nyambi". Responden tersebut tidak menyadari jika telah melakukan pola nafkah ganda.

Responden yang jelas jelas tidak dapat melakukan pola nafkah ganda adalah responden yang berprofesi sebagai bakul ikan di TPI. Hal ini disebabkan oleh jam kerja bakul ikan di TPI yang menyita 12 jam dalam sehari. Pekerjaan yang dilakukan di area pasar ikan TPI membuat responden berkutat dengan dagangannya saja dan tidak sempat melakukan kegiatan produktif pada bidang lain. Responden yang melakukan pola nafkah ganda adalah responden yang mempunyai warung sehingga masih ada kesempatan untuk melakukan kegiatan produktif pada sektor lain. Semua sektor pekerjaan memungkinkan untuk melakukan adanya pekerjaan sampingan, namun tergantung pada jam kerja dan kepadatan kegiatan pekerjaan utama.

\section{KESIMPULAN DAN SARAN}

\section{Kesimpulan}

Strategi nafkah yang dilakukan oleh perempuan nelayan di pesisir Sendang Biru meliputi: strategi nafkah dengan pola nafkah ganda atau tunggal, strategi nafkah dengan melakukan migrasi dan strategi nafkah dengan memanfaatkan sumberdaya keluarga. Faktor-faktor yang signifikan berhubungan secara positif dengan strategi nafkah adalah umur dengan optimalisasi sumberdaya keluarga, Etnik dan latar belakang etnik keluarga mempunyai keterikatan dengan pola nafkah dan migrasi dan jenis pekerjaan responden juga menentukan pola nafkah responden. Sedangkan faktor-faktor yang berhubungan negatif adalah tingkat pendidikan dengan optimalisasi sumberdaya keluarga dan dukungan sosial yang diterima responden berhubungan negatif dengan upaya melakukan migrasi.

Perempuan nelayan Sendang Biru yang berprofesi sebagai bakul ikan di TPI melakukan pola nafkah tunggal karena sebagian besar waktu tercurahkan pada satu jenis pekerjaan, hal ini berbeda dengan perempuan nelayan yang membuka warung di pinggir pantai sekaligus menjual ikan segar hasil tangkapan suami. Perempuan Nelayan Bugis dan Madura melakukan migrasi menyesuaikan musim panen dan musim paceklik di Sendang Biru. Keluarga perempuan nelayan yang melakukan optimalisasi sumberdaya keluarga adalah keluarga yang mempunyai anggota rumah tangga besar. Perempuan nelayan Sendang Biru juga melakukan strategi menabung sebagai upaya antisipasi ketika musim paceklik datang, seperti: membeli perhiasan emas, membeli kendaraan bermotor, membeli peralatan elektronik, dan menabung di bank konvensional.

Sebagian besar tingkat pendapatan perempuan nelayan mencapai di atas Rp1 500.000,-/bulan. Tingkat pendapatan tersebut berkorelasi positif dengan peningkatan pendapatan keluarga nelayan. Responden yang berprofesi sebagai bakul ikan mempunyai pemasukan rata-rata Rp3.000.000,-/bulan, pendapatan tersebut lebih besar dibanding pendapatan nelayan ABK yang rata-rata Rp2.000.000,-/bulan. Kontribusi pendapatan perempuan nelayan mencapai lebih dari $50 \%$ pendapatan rumah tangga. Hal ini dapat disimpulkan bahwa kontribusi pendapatan perempuan nelayan Sendang Biru meningkatkan pendapatan keluarga nelayan.

\section{Saran}

Berdasarkan hasil penelitian, maka terdapat beberapa hal yang dapat dijadikan masukan atau saran, di antaranya sebagai berikut:

1. Nelayan dan perempuan nelayan harus lebih bisa menyadari pentingnya kegiatan-kegiatan sosial yang dapat memberi pengetahuan positif di dalam kehidupan sosial mereka.

2. Pemerintah harus memperkuat adanya kelompok nelayan dan kelompok wanita nelayan sehingga mereka memiliki akses dan kontrol yang kuat terhadap programprogram pembangunan perikanan dan kelautan.

3. Perlu dilakukan penelitian yang berfokus pada pola migrasi yang terjadi di daerah Sendang Biru serta dampak sosial ekonomi yang terjadi.

\section{DAFTAR PUSTAKA}

Achmad S. 1993. Peningkatan Peran Wanita dalam Pembangunan dan Pengaruhnya terhadap Ketahanan dan Kesejahteraan Keluarga. [Internet]. [diunduh pada tanggal 15 November 2012]. Dapatdiunduhdarihttp://repository.ipb.ac.id/bitstream/ handle/123456789/24569/prosiding_keluarga_ menyongsong_abad_21.pdf

Ekaningdyah A. 2005. Peran Wanita dalam Peningkatan Pendapatan. Keluarga Nelayan Di DesaTasikagung KecamatanRembangKabupatenRembang 
[Internet]. [diunduh pada tanggal 15 November 2012]. http://eprint.undip.ac.id/5003/1/astridTA. pdf

Hanson AJ, Augustine I, Courtney CA, Fauzi A, Gammage S, dan Koesoebiono. 2003. The Assesment of The Coastal Resource Management Project (CRMP) in Indonesia. [Internet]. [diunduh pada tanggal 15 November 2012]. www.crc.uri.edu/ download/CRMP Assessment Final.pdf

[KKP] Kementerian Kelautan dan Perikanan Republik Indonesia. 2014. Kelautan dan Perikanan dalam Angka . [Internet]. [diunduh 18 Maret 2014]. http://statistik.kkp.go.id/

Kusnadi. 2003. Akar Kemiskinan Nelayan. Yogyakarta [ID]: LKiS

Nasution Z. 2007. SosialBudayaMasyarakatNelayan: Konsepdan IndikatorPemberdayaan. Jakarta [ID]: BalaiRisetKelautandanPerikananDepartemenKelautandanPerikanan, KKP. 147 hlm

2009. Dinamika Peran Gender dan Diseminasi Inovasi. Jakarta [ID]: BalaiRisetKelautandanPerikananDepartemenKelautandanPerikanan, KKP. $104 \mathrm{hlm}$

Nolan B. 2011. Ekonomi Politik Masyarakat Nelayan Skala Kecil: Sebuah Studi Perbandingan Masyarakat Pendatang di Rote Ndao dan Jawa Timur. [skripsi]. Malang (ID): Universitas Muhammadiyah Malang.

Nordholt HS dan Klinken Gv. 2007. Politik Lokal di Indonesia. Jakarta [ID]:KITLV press. $706 \mathrm{hlm}$.

Nugraheni WS. 2012. Peran dan potensi wanita dalam pemenuhan kebutuhan ekonomi keluarga nelayan. JESS. [Internet]. [diunduh 2014 Januari 20]; 1(20: 104-111. https://journal.unnes.ac.id/ sju/index.php/jess/article/view/739

Qurata VA. 2014. Perbandingan sistem bagi hasil tiga alat tangkap dan implikasinya pada kesejahteraan nelayan Desa Sendang Biru Kabupaten Malang. Jurnal Ilmu Perikanan Tropis.[Internet]. [diunduh pada 2015 Januari 28];19(4) : 85-92. https://unmul.ac.id\%2Fdo.php\%3Fdownf\%3Dff1c10-Vika-Perbandingan-Sistem-Bagi-Hasil-di-Tiga-Alat-Tangkap.pdf

Rachman A. 2013. Perilaku Ekonomi Nelayan Ikan Tuna Dalam Kerangka Industrialisasi Perikanan. [skripsi]. Bogor (ID): Institut Pertanian Bogor

Salamah. 2005. Peranan wanita dalam perekonomian rumah tangga nelayan di Pantai Depok Parangtritis Bantul. PKS. [Internet]. [diunduh 2015 Januari 30] ; 4(12) : 73-84. https://isjd.pdii.lipi. go.id/index.php/Search.html?act=tampil\&id= $47132 \&$ idc $=45$

Satria A. 2002. Pengantar Sosiologi Masyarakat Pesisir. Jakarta (ID): Cidesindo

2009. Pesisir dan Laut Untuk Rakyat. Bogor (ID). IPB Press

Singarimbun M. 1989. Metodedan Proses Penelitian. Singarumbun M dan Effendi S, editor. MetodePenelitian Survai. Jakarta [ID]: LembagaPenelitian, Pendidikan,dan Penerangan Ekonomi danSosial (LP3ES)

Suhaeti RN dan Basuno E. 2006. Integrasi Gender dalamPenguatanEkonomiMasyarakatPesisir.Soca.
[Internet]. [diunduh 20 Desember 2013]; 6(2) : 1-23. https://ojs.unud.ac.id/index/php/soca/3109

Suryana. 2010. Metodologi Penelitian: Model Praktis Penelitian Kuantitatif dan Kualitatif. [Internet]. [diunduh 13 Maret 2014]. http://file.upi.edu/Direktori/ FPEB /PRODI._MANAJEMEN_FPEB/ 196006021986011SURYANA/FILE _ 7.pdf

Suyanto B. 2003. Kajian Model Pemberdayaan Ekonomi Rakyat di Desa Pantai Madura dan Kawasan Selatan Jawa Timur. Surabaya [ID]: Lemlit Unair dengan Balitbang Propinsi Jatim

Widodo S. 2009. Strategi Nafkah Rumah Tangga Miskin Di Daerah Pesisir. [skripsi]. Bogor [ID] : Institur Pertanian Bogor

2011. StrategiNafkahBerkelanjutanBagiRumahTanggaMiskin Di Daerah Pesisir.Humanities. [Internet]. [diunduh tanggal 20135 Desember]; 15(6) : 10-20. https://http://journal.ui.ac.id/humanities/article/view/890/849

2012. PerananPerempuandalamSistemNafkahRumahTanggaNelayan.Seminar Nasional: Kedaultan Pangan dan Energi. [Internet]. [diunduh tanggal 5 Desember 2013]. http://agribisnis.trunojoyo.ac.id/peranan-perempuan-dalam-sistem-nafkah-rumah-tangga-nelayan.php

Zid M. 2011. Fenomena strategi nafkah keluarga nelayan: adaptasi ekologis di Cikahuripan-Cisolok, Sukabumi. Sosialita. [Internet]. [diunduh tanggal 20135 Desember]; 9(6): 32-38. http://fis.unj. ac.id/iai/sites/default/files/ sosialita.pdf 